\title{
アメリカの住宅建築におけるインターナショナル・スタイルの 形成過程に関する研究
}

\author{
THE INTERNATIONAL STYLE IN AMERICAN DOMESTIC ARCHITECTURE
}

\author{
熊倉洋介* \\ Yosuke KUMAKURA
}

\begin{abstract}
This paper is am attempt to clarify the development of the International Style in the field of domestic architecture before 1932. There seems to be three phases of the development. In the first phase, from 1907, four visible characteristics of the style apper. In the second phase, from 1926, some typical vocabularies are established. In the third phase, from 1930, popularizing of the style arise, but negative attitude in employing the typical vocabulary is noticeable.
\end{abstract}

Keywords : the international style, United States, modern architecture, house インターナショナル・スタイル，アメリカ，近代建築，住宅

\section{序 論}

これまでの近代建築史の議論においては, アメリカの インターナショナル・スタイルは 1930 年代にヨーロッ パから輸入されたものであるとする見方が支配的であっ た。特に, 多くのヨーロッパのインターナショナル・ス タイル建築をアメリカに紹介した「近代建築国際展」! が開かれ，同時にインターナショナル・スタイルを命 名・定式化した著作「インターナショナル・スタイ ルل方が出版された 1932 年以降, アメリカにおける同ス タイルの展開が活発化したと言われてきた。

ところが実際は，同展や同著作で取り上げられた作品 の中に，アメリカ国内の作品が含まれており，また 1920 年代後半から 1930 年代初頭にかけてのアメリカの 建築雑誌等にインターナショナル・スタイルと同様の形 式をもった国内の作品が散見される3)。こうしたことか ら，1932 年以前のアメリカにおいてもヨーロッパと並 行してインターナショナル・スタイルを形成する過程が あったと考えられる。しかしこれまでその過程を一連の 展開として具体的に検証した研究はなされていない。

そこで本研究は；1932 年以前のアメリカにおけるイ ンターナショナル・スタイルの形成過程の存在, および その具体的内容を明らかにすることを目的とする。本稿 での対象は住宅建築とし，ア゙メリカ近代建築史論，およ び外観デザインにかかわる意匠論の 2 つの観点から考察 する。

研究の具体的な方法は，1931 年までにアメリカ国内
で建設，あるいは計画された住宅作品のうち、インター ナショナル・スタイルに関係するものを取り上げ，主に 外観にかかわる意匠論的な作品分析を行い，それぞれの 作品をインターナショナル・スタイルの形成過程という 流れの中で位置付ける。

また，様式という観点から作品分析を行うにあたり， インターナショナル・スタイルの再定義が必要と思われ る。なぜなら前出の著作のなかでヒッチコックとジョン ソンは, 1.「ヴォリュームとしての建築」，2.「規則性」, 3. 「装飾付加の忌避」の3つの原理によってインターナ ショナル・スタイルを規定しているが，これらの原理に はその表現に抽象的な部分があって，作品分析の基準之 するには具体性に欠けること，また実例として示されて いる作品に例外が多いこと，などの問題点がある。さら に原理と並んでインターナショナル・スタイルを特徴付 けているものが，水平連続空やピロティを初めとする新 しい造形上の語曗や手法 (以下まとめて造形手法) であ ると思われるが，造形手法に関しては著者らは明確な解 釈や位置付けを行っていない。

そこで本研究では，同著作の論文および作品例の分析 を行い，原理が作品として具体的に視覚化された場合の インターナショナル・スタイルの特質（以下，視覚的特 質）を抽出し，それらにより同スタイルを再定義する。 さらに作品例に共通してみられる造形手法を取り出し, インターナショナル・スタイルにおける様式的な造形手 法として位置付ける。

* 東京都立大学大学院 大学院生 $\cdot$ 修士 Graduate Student, Graduate School of Tokyo Metropolitan University, M. Eng. 
まず第 1 原理「ヴオリュームとしての建築」に関する 記述を分析し，作品例をあわせて検討した結果，ヒッチ コックらの関心は,外壁を耐力壁に見せないことにあり， 具体的には外壁表面を連続的に平滑にすることが意図さ れていることが分かった。また「陸屋根は，本質的な美 学的重要性をもつ」文と述べ，作品例もすべて陸屋根を もつ建物であることから，彼らの言うヴォリュームとは 直方体のヴォリュームであると言えよう。これらのこと から，面の平滑性，および，直方体による構成，という 視覚的特質が導き出される。

次に第 2 原理「規則性」に関する記述では，等間隔の 柱配置や標準部材の同一性による規則性を問題にしてい るが，これらは絶対ではなく例外も認められるとしてい るため，特に視覚的特質とは見なさない。また多層建築 における規則性の現れとしての水平性について「イン ターナショナル・スタイルの最も顕著な特徴である」う と述べ，ファサードにおける水平性の表現を妥当なもの としている。作品例でも水平連続空などによって水平性 を強調したデザインがほとんどである。このため，水平 性の強調，を視覚的特質として取り上げる。

そして第 3 原理「装飾付加の忌避」は, 装飾の付けら れていない建物を正当化する具体的で明快な原理なの で，これに準じて，無装飾性，を視覚的特質とする。

以上のように，インターナショナル・スタイルの視覚 的特質として次の 4 つを抽出した。

1. 直方体による構成

2. 水平性の強調

3. 面の平滑性

4. 無装飾性

本論文では，インターナショナル・スタイル建築とは 上記の 4 つの視覚的特質を合わせ持つ建築であると定義 する。

また, 作品例の多くに共通してみられ, インターナショ ナル・スタイルを特徴付けている造形手法として次の 5 つが挙げられる。

・ルーフテラス

- 水平連続空

・コーナーウインドウ

-ピロティ

・キャンティレヴァー

ただしこれらの造形手法は視覚的特質とは異なり，イ ンターナショナル・スタイル建築が用いていなければな らない条件ではない。あるいはこれらの造形手法が用い られていても，4つの視覚的特質が満足されていなけれ ばインターナショナル・スタイル建築とは認めない。

本論文の構成は, 1932 年までのアメリカにおけるイ ンターナショナル・スタイルの形成過程を, その発達段

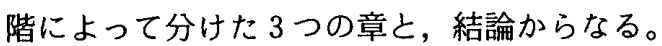

I . 萌芽段階, 1907 1925

インターナショナル・スタイルの形成の最初の段階 は, 視覚的特質の部分的な発現段階である。つまりイン ターナショナル・スタイル建築の出現する前段階の, 視 覚的特質のうちの幾つかが住宅作品に現れ始める段階で ある。また様式的造形手法の使用はこの段階ではまだ限 定的である。

1907 年に, まず直方体による構成, 面の平滑性, そ して無装飾性の $3 つ の$ 視覚的特質を備えた作品が現れ る。その作品を生み出したのはカリフォルニアで活動し た建築家，アーヴィング・ギル6)である。ギルが 1907 年にサンディエゴ近郊に建てたアレン邸（図一1）は, 当時まだ住宅としては例が少なかった鉄筋コンクリート を用いた壁構造による 2 階建ての建物である。

屋根は陸屋根で, 全体が一つの直方体の箱をなしてお り，ほとんよ゙の部屋がその直方体の中に収められている。 1 階のキッチンの一部だけがそのヴォリュームから突出 するが，その突出部分もやはり直方体で陸屋根を持つ。

外壁にはスタッコが塗られ，平滑に仕上げられている。 さらに，空台や屁などの外壁面から突出する要素を省い た開口部の処理（鎧戸は後年つけられたもの）や，2階 のバルコニーを外壁面より内側に設けていることなど が，建物に平滑性を与えている。

また，装飾的な要素は付加されていない。

このように, 直方体による構成, 面の平滑性, および 無装飾性という3つのインターナショナル・スタイルの 視覚的特質が認められる。

しかしもう一つの視覚的特質である水平性について は,バルコニーの開ロが横長のプロポーションになって

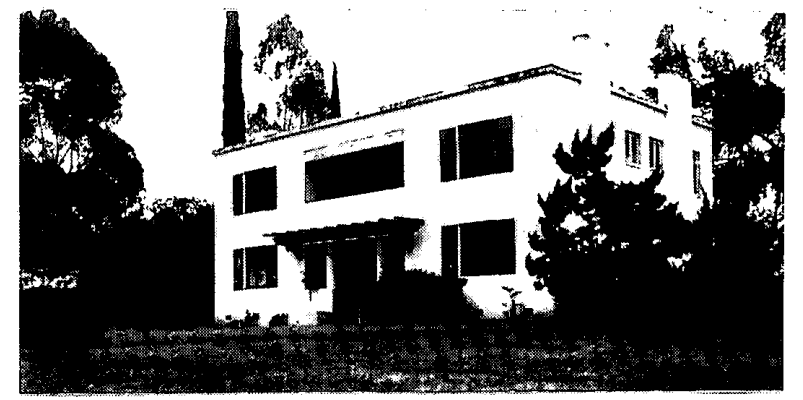

図一1 アレン邸，サンディエゴ近郊，I・ギル，1907

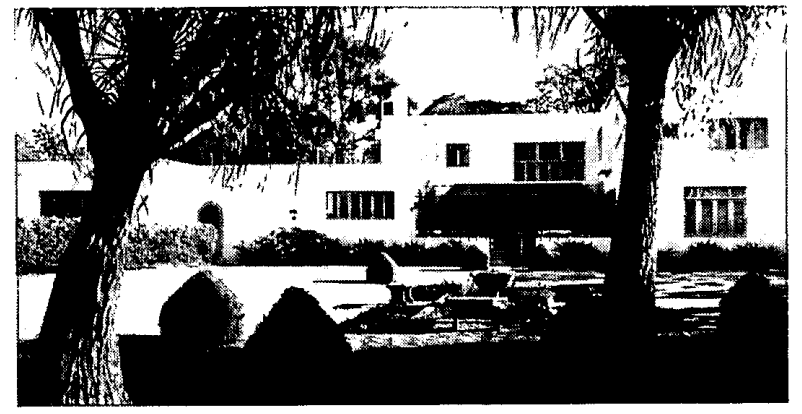

图一2ダッジ郖，ロサンゼルス，I・ギル，1916 
いるものの，縦長の窓が開けられているなよ゙，特に水平 性が強調されているとは言えない。

ギルが 1916 年にロサンゼルスに建てたダッジ邸（図 一2）はややはり鉄筋コンクリート壁構造による 2 階建 てで，いくつかの直方体を複雑に複合させた構成を持っ ている。外壁は平滑なスタッコ仕上げで, 開口部回りも アレン邸同様に突出物を省いて平滑に収められている。

また，アレン邸では特に認められなかった水平性がこ の作品には現れている。地面に沿って水平方向に伸びる 直方体の各ヴォリュームの配置の仕方や, 横長の空の多 用などによって，水平性が強調されている。

このようにこの作品には直方体による構成, 面の平滑 性, そして水平性の強調というインターナショナル・ス タイルの 3 つの視覚的特質が認められる。ところが, 一 部の出入口や中庭を囲む壁などにアーチ形の開口が用い られている。アーチは鉄筋コンクリート造にとっては構 造的合理性をもたない形態であり，伝統的な建築を連想 させる意匠であるため;一種の装飾的要素と考えられる。 故にこの作品は無装飾性をもつとは言えない。

1919 年にサンフランシスコ近郊パロアルトにクラー ク＆クラーク によって建てられたフーヴァー邸（図一 3）は，鉄筋コンクリート壁構造で, 直方体の複合によ る構成をもち，またスタッコ仕上げの外壁や突起物のな い開口部回りのおさまりなど面の平滑性も認められる。

ただし空のプロポーションが縦長であるなど, 特に水 平性の強調は意図されていない。また,アーチ形や装飾 的に扱われた階段状のモチーフなどが外観に現れてお り，無装飾性をもつとは言えない。

同じく 1919 年に, ギルはロサンゼルスにホラシオ・ ウエスト・コート（図一4）という隣接する4 住戸から なる集合住宅を建てる。構造は鉄筋コンクリートの壁構 造である。その 1 住戸に着目すると, 全体は 2 層分の直 方体 2 つ, 背後の 1 層分の直方体によって構成されて いる。また外壁はスタッコで平滑に仕上げられている。

この作品の特筆すべき点は, 水平連続空の採用である。 2 階の居間の周井 3 方向の壁に, ガラス空が横方向に連 続して設けられている。暖炬の煙突の部分以外, 隅部で はコーナーウインドウとなって途切れなく連続してい

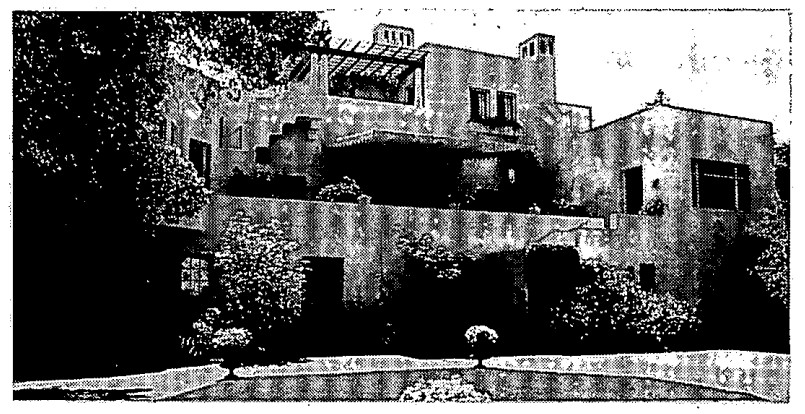

图一3 フーヴァー邸，パロアルト，クラーク\&クラーク, 1919

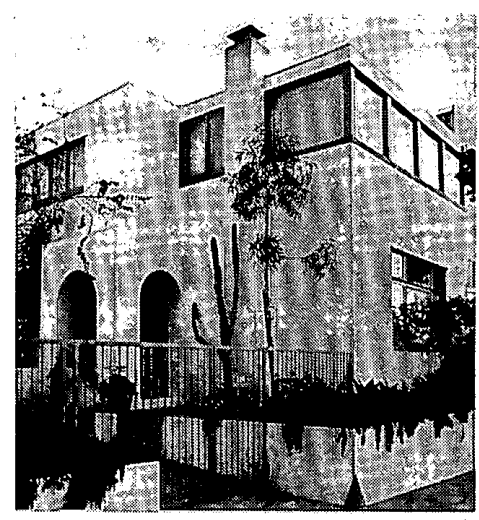

图一4 ホラシオ・ウエスト・コート，ロサンゼルス，I・ギル， 1919

る。この水平連続空の使用により，外観に水平性が与え られている。

このように直方体による構成, 面の平滑性, および水 平性の強調が認められる。しかし玄関ポーチにアーチが 用いられているため，無装飾性をもつとは言えない。

この作品でアメリカの住宅に初めて現れた ${ }^{8)}$ 水平連続 空, およびコーナーウインドウは, インターナショナル： スタイルの建築に特徴的な造形手法として頻繁に用いら れてゆく。このようにこの作品は無装飾性に欠けるため 萌芽段階に属するが，新しい造形手法を開発したという 点では次なる段階の先駆けと言える。

\section{II. 確立段階, 1926 1931}

1920 年代の前半には，まだ完全にインターナショナ ル・スタイルと呼べる住宅は現れない。1926 年以降，4 つの視覚的特質のすべてを備えた住宅作品が現れ始め て，インターナショナル・スタイルの展開は様式として の確立段階に移る。この段階では新しい構造形式が採用 されるとともに,革新的な造形手法が積極的に使用され， インターナショナル・スタイルの様式的造形手法として 定着する。

4 つの視覚的特質全部を備えた最初の作品は, 1926 年 にルドルフ・シンドラー9'がニューポート・ビーチに建 てたロヴェル・ビーチ・ハウス（図一5）である。従来 の壁構造にかわり，鉄筋コンクリートのフレームで支え

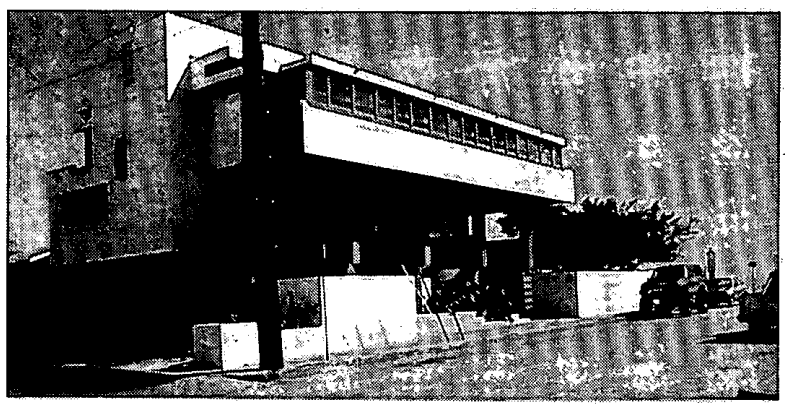

シンドラー, 1926 
られる構造形式が用いられている。全体はいくつかの直 方体から構成されている。前面 2 階のバルコニー $(1928$ 年頃にガラス空がはめられた）はキャンティレヴァーで 持ち出されており, 強い水平性を示している。バルコニー の下はピロティになっている。壁面はコンクリート打ち 放し，あるいはスタッコ仕上げで平滑である。また，装 飾的な要素は見られない。

このようにロヴェル・ビーチ・ハウスは直方体の複合 による構成, 水平性, 平滑性, そして無装飾性のすべて を備えた作品である。また同時に，住宅として初めてコ ンクリートのフレーム構造が採用され, それにともなっ てキャンティレヴァーやピロティなど新しい造形手法が 用いられた作品である。つまり，インターナショナル・ スタイルの展開が様式としての視覚的特質の獲得の段階 加ら, 独自の造形手法を開発して行く段階に移行したこ とを示す作品と言える。

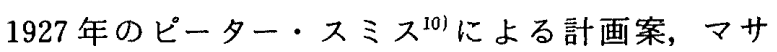
チューセッツの海辺の家（図一6）においても直方体に よる構成, 面の平滑性, そして水平連続空や横長のバル コニー等による水平性の強調が見られ，また無装飾性も 認められ，インターナショナル・スタイルの 4 つの視覚 的特質を備えた作品と言える。この計画案もフレーム構 造で設計されており, 独立柱で居室を持ち上げたピロ ティが見られる。また陸屋根をルーフテラスにしている。 さらに水平連続空とともにコーナーウインドウも用いら れている。このようにこの作品は革新的な造形手法が積 極的に取り入れられた進歩的な傾向を示す計画案と言え る。

ウィリアム・レスカーズ11による 1928 年の計画案, 末来のカントリーハウス案 (図一7) も直方体の複合に よる構成, 面の平滑性, 横長の空による水平性の強調,

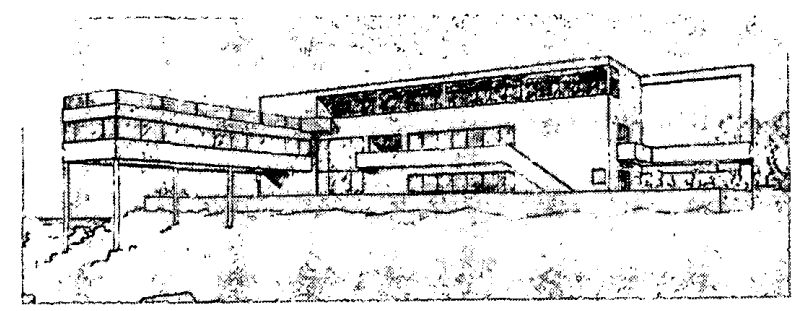

図一6 海辺の家計画案, ピーター・スミス, 1927

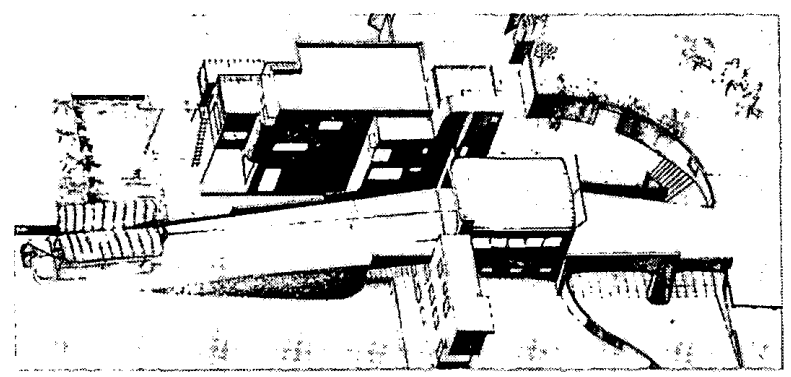

図一7 未来のカントリーハウス計画案, W・レスカーズ, 1928

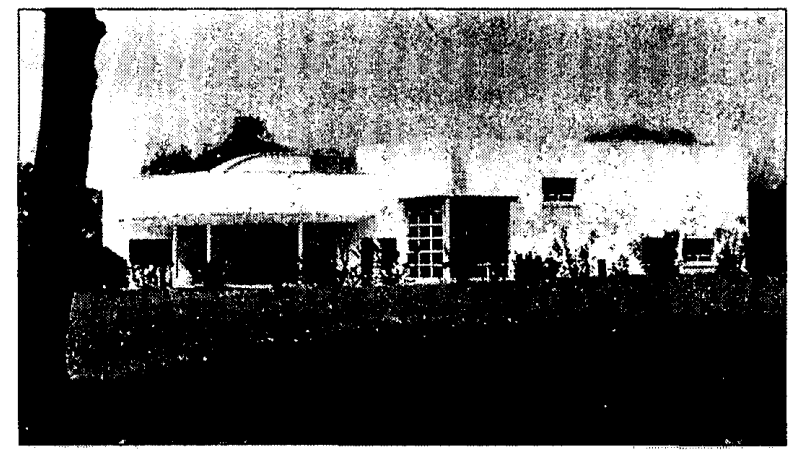

図一8 オークレーン保育園，オークレーン, 八ウ\&レスカーズ, 1929

そして無装飾性の各視覚的特質をもっており，またピロ ティ，ルーフテラス，キャンティレヴァーなどの新しい 造形手法が積極的に取り入れられている。またレスカー ズはこの前年にも「若いカップルのためのカントリーハ ウス」と題する計画案で, 同様のデザインを行っている。 これらのことから，ピーター・スミスの計画案とほぼ同 時期に，レスカーズも進歩的なインターナショナル・ス タイルの設計を行っていた事が分かる。

そしてレスカーズがこれらの計画案で示したアイデア を最初に実現したのが, 1929 年にジョージ・ハヴ ともにフィラデルフィア近郊オークレーンに建てたオー クレーン・デイ・スクールの保育園（図一8）である。 この作品は住宅ではないが，規模や機能面で住宅と共通 する部分が多い(3)ことから，インターナショナル・スタ イルの住宅の展開と関連が深いと考え, 特例として取り 上げる。

全体は居室の入る直方体と, ピロティで支えられた ルーフテラスから構成されている。外壁はスタッコが塗 られ，平滑性を示している。また，無装飾である。そし てルーフテラスの端部が支柱からキャンティレヴァーで 持ち出され，帯状のパラペットが水平性を強調している。 このように 4 つの視覚的特質を備えている。

そして造形手法としてピロティ,キャンティレヴァー， ルーフテラスに加え，大きなコーナーウインドウが用い られている。このようにこの作品は㬰施作品としてイン ターナショナル・スタイルの造形手法を積極的に用いた 例と言える。ところがその主体構造には予算の関係でコ ンクリート・ブロック造が採用されている。ピロティと コーナーウインドウは部分的に鉄骨の独立柱を用いるこ とによって可能になっているもので，それらは主体構造 と合致した合理的なものとは言えない。

主体構造のシステムと合致した合理的なやり方によっ てインターナショナル・スタイルの造形手法が用いられ ている例が, 同じく1929年にリチャード・ノイトラ ${ }^{14)}$ がロサンゼルスに建てたロヴェル邸（図一9）である。 この作品は主体構造を鉄骨造とした最初の住宅である。 


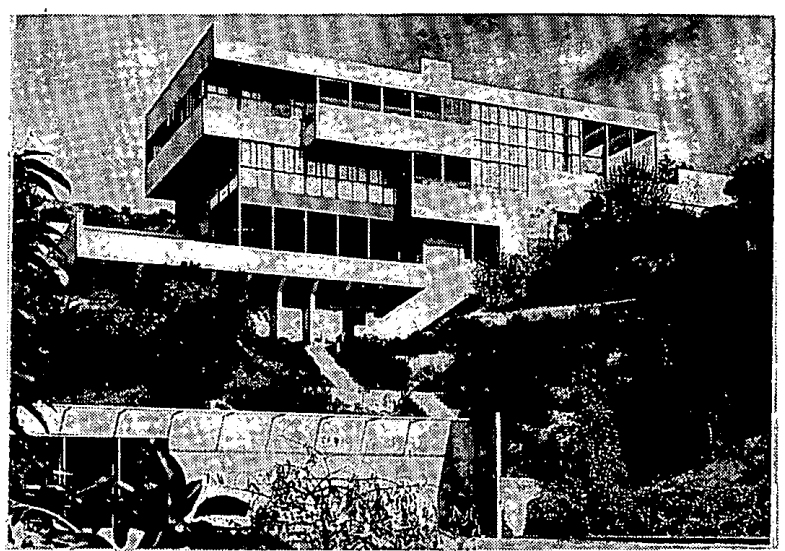

図一9 ロヴェル厤，ロサンゼルス， R・ノイトラ, 1929

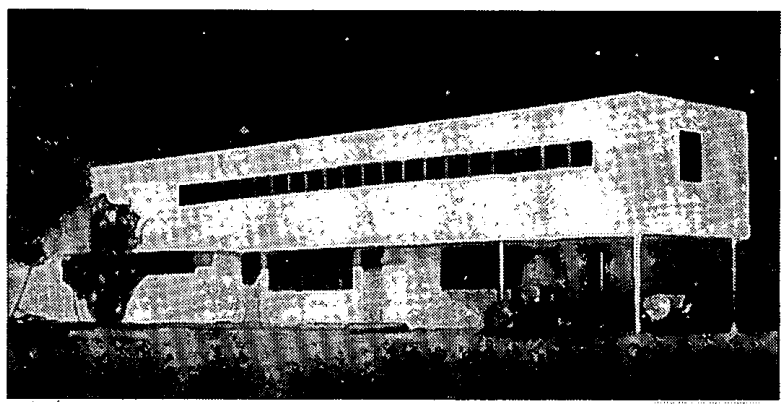

图一10 ジョンソン夫人邸計画案, クラウス＆ダウブ, 1931

均等に配置された柱梁のグリッドに従って直方体のヴォ リュームが複合する構成をもち, 水平方向に連続する吹 き付けコンクリートのスパンドレルが著しい水平性を示 している。外壁の柱とガラスとスパンドレルはほぼ同面 に納められ, 面の平滑性を示している。また装飾的要素 は排除されている。

このように 4 つの視覚的特質を備え,さらにピロティ, キャンティレヴァー(実際は吊り構造), 水平連続空, コー ナーウインドウなどの造形手法が構造の率直な表現とし て合理的に用いられている。この作品はその構造形式, そして造形手法の合理的な使用から，確立段階における インターナショナル・スタイルの最も進んだ実例と言え る。

クラウス\&ダウブ15)が 1931 年にパインハーストに計 画したジョンソン夫人邸案（図一10）は，2つの直方体 がずれて重なる構成をもつ。上階のヴォリュームは大部 分ピロティで持ち上げられていることで独立した純粋な 6 面体として認識され, その結果建物に抽象的な性格が 与えられている。また，そのヴォリュームの横長のプロ ポーションや水平連続空が水平性を強調しており,さら に面の平滑性と無装飾性も認められ，4つの視覚的特質 をすべて備えていると言える。このようにこの計画案は， 建物の抽象性を強調する手段としてピロティが効果的に 用いられている例である。

コーカー\&フレイ ${ }^{16)}$ が 1931 年に, ある建築展 ${ }^{17)}$ のた めに製作した「アルミネアー」(図一11) も，積極的に

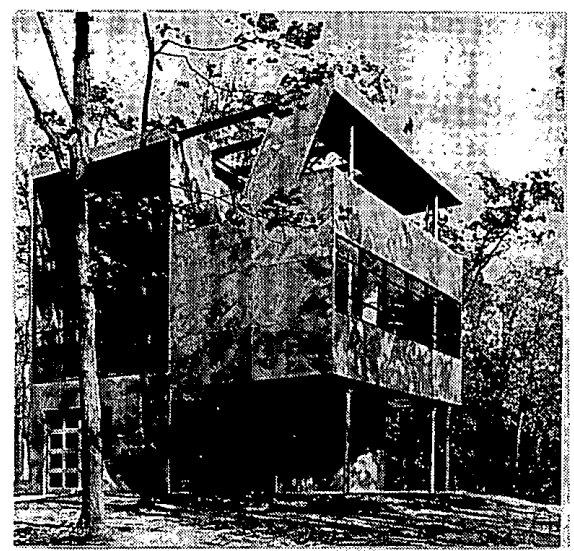

図一11 アルミネアー, ショゼット,コーカー\&フレイ, 1931

インターナショナル・スタイルの造形手法を用いた住宅 作品である。全体がひとつの直方体で, ポーチとルーフ テラスがそこからヴォイドとして抜けた構成をもつ。外 壁はアルミ板張りで突起物もなく平滑である。装飾性は ない。アルミパイプによるフレーム構造が採用されてお り，外壁はキャンティレヴァーでもちだされたスラブで 支えられている。この建物のフレームとキャンティレ ヴァーによる構造形式は, 外壁面より内側に立つピロ ティの独立柱の存在で外部に示されているとともに, 耐 力壁構造では不可能な大面積のガラス空や立面の幅いっ ぱいの水平連続窓によっても暗示されている。また水平 連続窓は水平性を強調する要素でもある。この作品にお けるピロティの効果は, 前出の作品のような抽象性の強 調より，構造形式を外観に示すところに現れていると言 えよう。

\section{III. 普及段陼, 1930 年以降}

インターナショナル・スタイルの住宅の展開は, 革新 的な造形手法を追及する確立段階が 1931 年頃まで続く が，1930年を過ぎると徐々に次なる段階への移行が見 られ始める。一部の限られた建築家たちによって革新的， あるいは前衛的なデザインとしてインターナショナル・ スタイルが追及された確立段階とは異なり，1930 年代 を通して見られる次の段階では，インターナショナル・ スタイルは時代の求める流行のスタイルとして広く普及 していく。本章ではこの 2 つの段階の移行期である 1930 年から 1931 年にかけて見られた, 普及段階の初期 の代表例を取り上げる。

レイモンド・フッド18)が 1930 年にオッシニングに建 てたパターソン邸 (図一12) は, 直方体が複合した構成, 突起物のない外壁の平滑性, 立面のプロポーションや横 長の公によって感じられる水平性，そして無装飾性（た だし施主の要請により迷彩塗装された)をもつ,インター ナショナル・スタイルの 4 つの視覚的特質を備えた作品 である。しかしその構造が壁構造であるためインターナ 


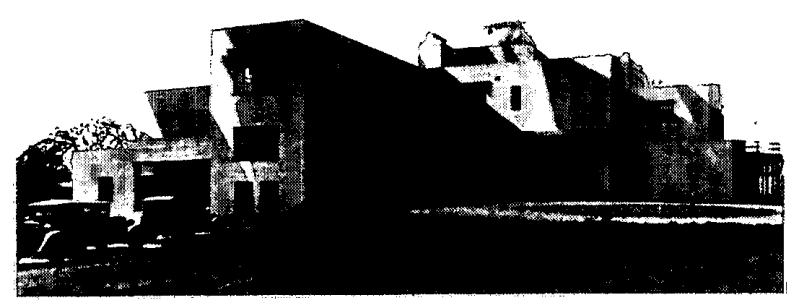

図一12 パターソン邸, オッシニング, R・フッド, 1930

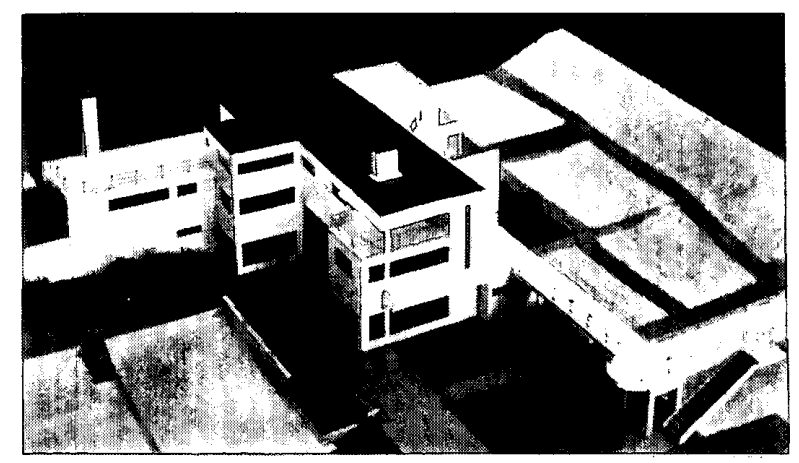

図一13 砂丘の夏の家計画案, W・マッシェンハイム, 1930

ショナル・スタイルの造形手法の採用には制限があり， ルーフテラス以外には特に用いられていない。

ウィリアム・マッシェンハイム ${ }^{19)}$ が 1930 年に発表し たロングアイランドの砂丘の夏の家の計画案（図一13） も，直方体の複合による構成，突起物の排された平滑な 外壁面, 横長の葖による水平性の強調, そして無装飾性 をもつ,インターナショナル・スタイルの 4つの視覚的 特質を備えた作品である。しかし造形手法に関しては, フレーム構造で設計されているのだからピロティやキャ ンティレヴァーの採用が可能であるにもかかわらず，そ れらは用いられていない。また空はその横幅が柱間に限 定されているために単なる横長の空であり，水平連続空 とは言えない。

これらのような，革新的な造形手法の採用には積極的 ではないがインターナショナル・スタイルとしての視覚 的特質は備えている作品が数多く現れたことが, 普及段 階の大きな特徵である。これはピロティやキャンティレ ヴァーなど技術的, 平面計画的に困難の伴う手法は採用 しがたいが，新しい流行のデザインは取り入れたいとい う保守的な建築家の意識の現れと考えられる。特にボ ザール派の建築家であり，それまでは様式主義的なデザ インを行っていたフッドがこうした作品を作ったこと は，インターナショナル・スタイルが一般に普及しはじ めたことを端的に語る事実といえよう。つまりインター ナショナル・スタイルのデザインが一部のアヴァンギャ ルドだけのものではなく，保守的な建築家の作品にも取 り入れられるようになったのがこの普及段階である。

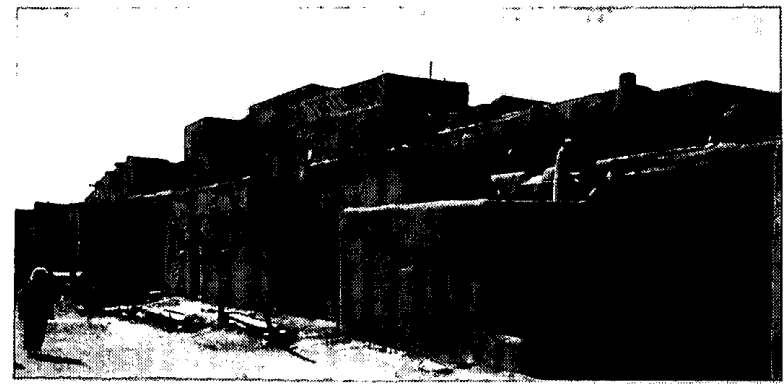

图一14 プェプロ・インディアンの住居, ニューメキシコ, 1700 頃

\section{結 論}

研究の結果, 以上のように 1932 年以前のアメリカに インターナショナル・スタイルを形成する動きが存在し ていたことが明らかになった。通常アメリカのインター ナショナル・スタイルは, ヨーロッパのそれの輸入とい う観点からのみ認識されているが，実際はアメリカ国内 にもインターナショナル・スタイルを誕生させる素地が あったと考えられる。

例えば，ギルの仕事によってインターナショナル・ス タイルの視覚的特質が生み出されたことは I 章で述べた が, ギルはヨーロッパの影響をほとんど受けていない建 築家である。彼はシカゴのルイス・サリヴァンの事務所 などで修行した後カリフォルニアで独立して活動する が，渡欧の経験はなく，ヨーロッパの建築家との交友も 1920 年代になるまでなかった。彼が興味をもっていた のはアメリカ西部のスパニッシュ・ミッションとプエブ ロ・インディアンの建築であったとギル自身が述べてい る20)。このプエブロ・インディアンのアドービ（日干し レンガ) 造建筑（図一14）は極めて単純なもので, 陸屋 根をもつ直方体が基本となって構成されており，外壁は 泥モルタルが塗られて平滑に仕上げられている。また横 に連続して建てられるために水平性が強調され，しかも 装飾的な要素がほとんど無い。つまりプエブロ・イン ディアンの建築にインターナショナル・スタイルと共通 する視覚的特質を見いだすことが可能である。あるいは また，伝統的なニューイングランド・コロニアルの住宅 のデザインに，インターナショナル・スタイルの視覚的 特質につながる単純性を指摘することも容易である。

こうしたアメリカの建築が伝統的にもっている単純性 指向がインターナショナル・スタイルの形成を準備する 下地となっていると言えよう。

もうひとつインターナショナル・スタイル形成の下地 となっているものに建築技術の発達がある。アメリカに おける鉄筋コンクリートの技術は 19 紀末， ヨーロッパ とほぼ同時期に独自に開発された。また鉄骨造の技術は やはり19世紀末にシカゴの高層建築などに用いられて 発達していた。これらの新しい建築技術は当初は主に商 業建築や工業建築に用いられており，そこではキャン 
ティレヴァーや水平連続窇などの造形手法が部分的に開 発されていた。そして今世紀に入った頃からまずプレ ファブ住宅に鉄筋コンクリートが使われ211，以後次第に 住宅の分野にも新しい技術が応用され始める。こうした アメリカの技術力を背景に，シンドラーやノイトラらは 革新的な造形手法を実現して行く。特にノイトラによる アメリカ初の鉄骨フレーム構造のロヴェル邸は当時, 近 代建築の理想を夷現したものとしてヨーロッパでも高く 評価された。

ただしこうしたインターナショナル・スタイルの形 成を担った建築家には，ヨーロッパからの移住建築家が 少なくない。特に確立段階ではヨーロッパの近代運動に 身近に接した経験をもつシンドラー,ノイトラ,レスカー ズクラウス，フレイらが主導的な役割を演じた。また スミス，ハウ，フッド，マッシェン八イムらも渡欧経験 をもっており，彼らも何らかの形で近代運動の影響を受 けていたと言える。こうした各建築家のバックグラウン ドから考えても, 1920 年代後半にはヨーロッパとアメ リカの間の地域的な格差は小さくなっており，インター ナショナル・スタイルは大西洋を挟んで並行して発展し ていたと見ることが出来る。

以上をまとめて考えると，アメリカのインターナショ ナル・スタイルは, アメリカ建築に伝統的な単純性と, 19 世紀末の技術革新, それにヨーロッパの近代運動が 結び付いて 1920 年代後半に花開いたものだと言える。

そして 1930 年を過ぎると次第にアメリカでインター ナショナル・スタイルの一般化が始まり，而章で取り上 げたような作品が現れて来る。それらはアメリカ人の建 築家がインターナショナル・スタイルに興味をもち, 自 身の設計に取り入れ出した結果である。

こうして見ると, 1932 年に開かれた「近代建築国際展」 や同年出版の『インターナショナル・スタイル」にアメ リカ国内の例が含まれているのは当然と言える。しかし それ以後, 数多くのインターナショナル・スタイルの住 宅作品が作られたにもかかわらず，確立段階に見られた ような革新的なデザインをもったものはほとんど現れな い。デザインの質という観点から見れば，1930年代の インターナショナル・スタイルは 1920 年代の作品の部 分的な模做を繰り返す不毛なものであると言える。

注

1）この展覧会の内容に関しては，以下の資料が詳しい。 The Museum of Modern Art : Modern Architecture/International Exhibition, reprint Arno Press, 1969

Riley, Terence : The International Style/Exhibition 15 and The Museum of Modern Art, Rizzoli, 1992

Stephens, Suzanne : Looking Back at "Modern. Architecture" The International Style Turns 50, Skyline, pp. 18 $\sim 27,1982.2$
Wilson, Richard Guy: The International Style; The MOMA Exhibition, Progressive Architecture, pp. 89 $105,1982.2$

2) Hitchcock, Henry-Russell and Johnson, Philip : The International Style, 1932 1966, 武澤秀一訳, 「インターナ ショナル・スタイル」, 鹿島出版会, 1978

3）予備調査として, 当時の主要な建築雑誌 American Architect, Architectural Forum, Architectural Record, Architecture, Journal of American Institute of Architects $の$ 1922 年から 1932 年までに発行された号に目を通した。 その結果, インターナショナル・スタイルと同様の形式 をもつ作品は 20 数例を数えた。また 19221年以前の作品 に関する資料については作品毎に付した注を参照。ただ し本稿の目的は網羅的になることよりも大きな流れの検 証にあるので, 重要な作品のみを取り上げた。

4）ヒッチコックとジョンソン, 武澤訳前掲書; p. 55

5）ヒッチコックとジョンソン, 武澤訳前揭書, p.79

6) Irving J. Gill (1870－1936）ギルに関する参考文献 Anderson, Timothy J. et. al. ed. : California Design 1910, 1974, reprint Peregrine Smith Books, 1989 Jordy, Wiliam H. : American Buildings and Their Architects Vol. 4 / Progressive and Academic Ideals at the Turn of the Twentieth Century, paperback, Oxford University Press, 1986

Kamerling, Bruce : Irving Gill/The Artist As Architect, The San Diego.Historical Society, 1979

McCoy, Esther : Five California Architects, 1960, reprint Hennesey and Ingalls, 1987

Scully, Vincent : American Architecture and Urbanism, 1969, 香山寿夫訳,「アメリカの建築とアーバニズム】, 鹿島出版会, 1973

7) Arther B. Clark (?〜?) と Birge M. Clark (1894 ?) の父子。广ーサーはスタンフォード大芸術学部教授, バー ジは1914 年スタンフォード大卒, 1917 年コロンビア大 建築学科卒。

フーヴァー邸に関する資料

Woodbridge, Sally B. : California Architecture/Historic American Buildings Survey, Chronicle Books, 1988, p. 181

8) エスター・マッコイはある雑誌記事で, この水平連続空 が後に増築されたものである可能性について語っている。 しかし同時にマッコイは，1930 年に出版されたノイトラ の著書 Amerikaに揭載されたこの作品の写真にすでに水 平連続空が見られることを指摘している。

また，シンドラーのシンドラー\&チェイス邸に関する 文献に，クライド・チェイスがェンジニアとして 1921 年 にホラシオ・ウエスト・コートの工事を担当した事実が 述べられている。これらのことから判断すると，1919 年 に一旦完成した建物のテラスに，2 年後に屋根をかける 増築工事が行われた可能性が大きい。しかし 1921 年だと しても水平連続空の最も早い例であることにかわりない。 McCoy, Esther : Horatio West Court, Progressive Architecture, Vol.57, pp. 68 69, 1976.11

Neutra, Richard J. : Amerika, Verlag Von Anton Schroll \& Co. Wien, 1930, pp. 118 119

Smith, Kathryn :R.M. Schindler House 1921 1922, Friends of the Schindler House, West Hollywood, 1987, 
p. 17

9) Rudolph M. Schindler (1887〜1953) オーストリア生ま

れ, 1917 年移住。

シンドラーに関する参考文献

Gebhard, David : An Exhibition of the Architecture of R.M. Schindler, University of California, 1967

McCoy, Esther : Five California Architects

Sarnitz, Augusto: $R: M$. Schindler/Architect 1887 1953, Rizzoli, 1988

10) Peter van der Meulen Smith (1902 1928)

ハーヴァード大学卒, ボストンの設計事務所勤務後,

1926 年末か 1927 年始めにパリのアンドレ・リュルサの

事務所に入り，ル・コルビュジエ, J.J.P. アウトらと親

交を結ぶ。1928 年冬にベルリンで病死。

スミスに関する参考文献

Hitchcock, Henry-Russell : Modern Architecture/Romanticism and Reintegration, 1929, reprint AMS Press, 1972 Hitchcock, Henry-Russell : Four Harvard Architects, Hound \& Horn, Vol. 2, pp.41〜47, 1928.9 ちなみにこの 文章の中でヒッチコックが初めて “International Style” という言葉を用いている。

J.J.P. Oud: In Memory of Peter van der Meulen Smith, 1902 1928, International Review 10, 1929.2, pp. 122 123

Searing, Helen : International Style/the Crimson Connection, Progressive Architecture, 1982.2, pp. 88 91

11) William Lescaze $(1896$ 1969) スイス生まれ, 1920 年 移住。

レスカーズに関する参考文献

Hubert, Christian : William Lescaze, Rizzoli, 1982

Lanmon, Lorraine Welling: William Lescaze Architect, Art Alliance Press, 1987

また, Lescaze の米国での一般的な発音の表記としては 「レスケーズ」より「レスカーズ」が近い。

12) George Howe (1886 1955)

13）この保育園の平面構成は, エントランス・ホール, クラ スルーム 1 室, ベッドのおかれた中 2 階, バスルーム, キチネットから成っている。

14）Richard J. Neutra (1892〜1970) オーストリア生まれ, 1923 年移住。

ノイトラに関する参考文献

Boesinger, W. : Richard Neutra/Buildings and Projects, Editions Givsberger, Zurich, 1951

Drexler, Arther and Hines, Thomas S. : The Architecture of Richard Neutra/From International Style to California Modern, The Museum of Modern Art, 1982

Hines, Thomas S. : Richard Neutra and Search for Modern Architecture, Oxford University Press, 1982

15）Alfred Clauss (1906〜?) ドイツ生まれ，1926 年ミュン ヘン建築大卒後, 渡米し 1930 年からハウ\&レスカーズ。 George Daub (1901〜?) は1925 年ハーヴァード大卒,
1928 年からハウ\&レスカーズ。

16) Lawrence Kocher (1885 1969) はMIT 卒, 設計活動の かたわら 1928 年からアーキテクチュラル・レコードに参 加。

Albert Frey (1903？) は1924 年スイスのウインター ザー工科大卒後ル・コルビュジエのアトリエ勤務。1930 年渡米しコーカー\&フレイ。

フレイに関する参考文献

Rosa, Joseph : Albert Frey, Architect, Rizzoli, 1990

17）アルミネアーが出品されたのは，1931 年 4 月にニュー ヨークのグランド・セントラル・バレスで開かれた「建 築及び関連芸術展」と題する展筧会で，この展覧会は ニューヨーク建築連盟展と合同で開かれたものであった。 アルミネアーはこの展覧会で 8 日間展示された後, ロン グアイランドのショゼットに移築された。

Rosa, Joseph : ibid., pp. 27 28

18) Raymond M. Hood (1881 1934) に関する参考文献 Kilham, Walter T. : Raymond Hood, Architect, Architectural Book Publishing, 1973

Stern, Robert A. M. : Raymond Hood, Rizzoli, 1982

19) William Muschenheim (1902 ?) 1924 年 MIT 卒, 1929 年ウイーンのベーレンス・マスター・スクール卒, 1930 年からニューヨークで設計活動。 マッシェンハイムに関する参考文献

Design by William Muschenheim New York, Architectural Record, Vol. 68, pp. 321 326

20) Gill, Irving: "The Home of the Future, The New Architecture of the West, Small Homes for a Great Country, By Irving John Gill, Number Four", Craftsman, Vol. 30, pp. 140 151, 220, 1916. 3

21）コンクリート建築の初期の状況に関する資料

Hatheway, Roger and Chase, John : "Irving Gill and the Aiken System", Concrete in California, Carpenters/Contracters Cooperation Committee of Southern California, 1990

\author{
図版出典 \\ 図一1,3,4,5,14 著者撮影 \\ 図-2 McCoy : Five California Architects, p. 91 \\ 図-6 Hitchcock: Modern Architecture, Fig. no. 53 \\ 図-7 Hubert: ibid., p. 23 \\ 図-8 The Museum of Modern Art : ibid., p. 151 \\ 园-9 Hines : ibid., p. 85 \\ 困-10 Architectural Record, Vol. 70, p. 362, 1931.11 \\ 図-11 Rosa: ibid., p. 41 \\ 図-12 Stern: ibid., p. 79 \\ 図-13 Architectural Record, Vol.68, p. 323, 1930.10
}

(1992 年 5 月 10 日原稿受理, 1992 年 11 月 19 日採用决定) 